\title{
Challenges in using frog VLE in teaching english to ESL learners: a review of past studies
}

\author{
Siti Sarah Shazali ${ }^{1}$, Harwati Hashim ${ }^{2}$ \\ ${ }^{1}$ Sekolah Kebangsaan Seri Selangor \\ ${ }^{2}$ Universiti Kebangsaan Malaysia
}

\section{Article Info \\ Article history: \\ Received Nov $3^{\text {rd }}, 2018$ \\ Revised Nov $15^{\text {th }}, 2018$ \\ Accepted Nov 24 ${ }^{\text {th }}, 2018$ \\ Keyword: \\ Virtual Learning Environment Frog VLE; \\ English as a Second Language \\ ESL Learners; \\ Teaching English using \\ technology}

\begin{abstract}
In the era of 21st century teaching and learning, technology has been widely used among educators especially in teaching of English Language. Many studies have proven that teaching through the use of technology such as media socials, video conferencing, Frog Virtual Learning Environment and other mediums help in increasing the knowledge and usage of the English Language. This paper aims to review challenges encounter by teachers when using Frog VLE in teaching English to English as a Second Language (ESL) learners particularly in primary and secondary schools in Malaysia. This paper reviews journal articles, books and other researches to identify the challenges in using technology especially the use of Frog VLE. The review of past studies has shown that challenges did occur during the implementation of Frog VLE. Thus, this paper puts forth a proposition that more research should be conducted on teachers' perceptions towards the use of Frog VLE in classroom teaching. Add on sentence to conclude and highlight the implication.
\end{abstract}

(C) 2018 The Authors. Published by Redwhitepress.

This is an open access article under the CC BY-NC-SA license

(https://creativecommons.org/licenses/by-nc-sa/4.0/

\section{Corresponding Author:}

Siti Sarah Shazali

Sekolah Kebangsaan Seri Selangor

Email: harwati@ukm.edu.my

\section{Introduction}

English language is known as a global language. People all around the world use English for communication and interactions. Some use it in education and policy making. In Malaysia, Bahasa Malaysia is the national language, Chinese and Tamil are considered as mother tongue. English language is an important second language. It has to be taught in schools so that Malaysians who have undergone the national education system are able to communicate in the language (Ying, Abdullah \& Tan, 2018). It does not require the children to speak like the native speakers but rather to grasp the language and able to use the language with their peers and people all over the world (Sharifian, 2018).

English language has been known as a compulsory subject in school. This shows in the need to obtain a pass especially in 'Sijil Pelajaran Menengah' (SPM) in order to qualify themselves for the certificate (Malaysian Education Blueprint, 2016). Every Malaysian student under the education system has to go through three main formative examinations such as 'Ujian Penilaian Sekolah Rendah' (UPSR), 'Pentaksiran Tingkatan 3' (PT3) and 'Sijil Pelajaran Menengah' (SPM). In these three examinations, English language is considered as a core subject (Darus, 2010). As it is a second language, the government has come up with many initiatives, for teaching and learning process of the language. One of the initiatives is through the use of Information and Communications Technology (ICT) (Frog Asia, 2014). 
In this paper, the aim is to review challenges encounter by teachers when using Frog VLE in teaching English to English as a Second Language (ESL) learners particularly in primary and secondary schools in Malaysia. This paper starts with a review of ICT in education, followed by technology for teaching English, and then the discussion on the challenges and barriers in using Frog VLE.

\section{Ict In Education}

Information and Communications Technology (ICT) can be defined as a diverse set of technological tools and resources used to communicate, and to create, disseminate, store, and manage information. These technologies include computers, the Internet, broad-casting technologies (radio and television), and telephony (Tinio, 2003). However, ICT in education refers to both an array of tools and also to the principles for their effective application in learning. Educational technology relies on a broad define methodologies and techniques, and skills assessments. Examples of these two dimensions are material aspects such as internet-based learning, and educational psychology aspects such as instructional theory, learning theory, media psychology and human performance technology, fields of study that apply theories of human behaviour to educational technology (Sudhir \& Sunil, 2015) .

Students in today's generations are advanced in the use of technologies and teachers are no longer encouraged to use only the traditional methods but rather to integrate traditional and modern methods together in their teaching (Jani, Muszali, Nathan \& Abdullah, 2018). Modern methods here refer to blended learning where it is the current teaching technique being discussed and the one that has already been implemented in school, Virtual Learning Environment (VLE). Thus, to achieve this, the government has provided teachers with YES Altitude smartphones and Lenovo tablets (Malaysia Education Blueprint, 2016). This is to enhance the usage of ICT in teaching among the teachers in Malaysia. It is also to enable them to share educational materials and provide learning 'anywhere, anytime'.

\section{Technology For Teaching English}

A virtual learning environment (VLE) is a set of teaching and learning tools designed to enhance a student's learning experience by including computers and the Internet in the learning process. Students can access assignments or tasks given in their respective accounts and teachers are able to evaluate and analyse which area their students need attention the most. In line with the 21st Century learning in the classroom, Ministry of Education (MOE) has launched the new Malaysia Education Blueprint (2013-2025). Malaysia Education Blueprint suggests 11 strategic and operational shifts required to transform the system and achieve the vision of 21st century education. Shift 7 aims to "Leverage ICT to scale up quality learning across Malaysia" (Malaysia Education Blueprint, 2016), thus the MOE implemented Virtual Learning Environment (VLE) and Frog VLE is one of the platforms to achieve this aim.

A virtual learning environment like Frog VLE provides a platform for individualized learning as it allows instructors and students to share instructional materials, make class announcements, submit and return course assignments, and communicate with each other through online platforms (Nambiar, Nor, Ismail \& Adam ,2017). The Frog VLE (Frog Asia, 2014) is a web-based learning system that replicates real-world learning by integrating virtual equivalents of conventional concepts of education. This is one of the blended learning strategies that is currently debated about. Frog VLE was provided by MOE via 1BestariNet for all 10,000 schools in 2013. It links schools across Malaysia via internet with their YES 4G connectivity. The teachers have been using VLE Frog in their teaching and learning to create a fun and exciting environment rather than the traditional method of "Chalk and Talk".

\section{Challenges and Barriers In Using Frog Vle}

Frog VLE is a learning management system which the Malaysian government has adopted for all its 10,000 government aided schools nationwide (Cheok M.L., \& Wong S.L, 2016). Few challenges have been identified in using Frog VLE in schools particularly in teaching and learning. The difficulty of accepting new educational innovation or learning tools introduced by the education sector is one of the challenges faced by teachers especially senior teachers. As reported in Harun et al. (2016), only young teachers prefer to use ICT compared to senior teachers. Most of senior teachers felt difficult to accept this new innovation and the changes made to integrate ICT in their teaching. Teachers believed that it does not have a long tradition in language teaching and their lack of experience in involving the students to control over their own learning through interactive activities (Suo \& Suo, 2018). Moreover, change brings with it a certain amount of anxiety and threat. Teachers are reluctant to change because they are unsure if they can make the new practices work (Ball, 2003).

As change means risking failure, teachers do not easily alter or discard the practices they have long developed and refined (Bolster, 1983). This claim is supported by Razali et al. (2017), through their research findings that teachers find it difficult and a waste of time learning ICT skills especially senior teachers. However, if provided more sufficient training, teachers' skills in accessing Frog VLE will be more 
efficient hence, making them wanting to use it in their teaching and learning. In a case study conducted by Kaur \& Hussein (2015), it was proven that by attending ICT training, teachers improved their basic knowledge and usage of ICT. Therefore, if the teachers are given more courses or training on how to use Frog VLE, it is no doubt that they will apply it in their classroom teaching as they are comfortable in using it. This statement is supported through an interview conducted by Saruji, Hassan and Drus (2017) stated that teachers seem to find it easy to use Frog VLE as the students' username and password are provided and that they are in a comfortable atmosphere. Thus, relevant parties should continue monitoring to ensure that teachers feel comfortable utilizing the program at any time especially in integrating it in their teaching (Kaur \& Hussein, 2014).

The main purpose of Frog VLE is to create borderless learning environment and self-directed learning for students with the presence of internet connectivity (Nithia et al., 2015). Without the presence of internet connectivity, Frog VLE cannot be integrated in teaching and learning making it one of the challenges faced by teachers as well as students (Rani et al. ,2014). Furthermore, Kamalludeen et al. (2016) stated that students faced unavailability of internet access due to parental control making it difficult for them to use the program at home. The finding of Cheok et al. (2017) claimed that almost all of the respondents complained of slow internet connection made it difficult for them to have access to Frog VLE. Due to such constraint, teachers prefer the traditional face-to-face approach.

According to Razali et al. (2016), lack of facilities including internet access that teachers chose to teach using conventional approach as it worked and increased students' achievements. Moreover, students' achievements are seen crucial, forcing teachers to prepare students for major exams because results matter and it is time consuming effort to produce teaching materials online thus increasing teachers' workload (Kaur \& Hussein, 2015). A research was conducted in a suburban area in one of the states in Malaysia shows that teachers are keen on using ICT in preparing examination papers, analysing students' achievement and notes rather than using it in the classroom (Hassan \& Kamisan, 2010). Nonetheless, Songkram et al. (2015) stated that integration of ICT in students' learning process would increase students' achievements. Hence, through this claim, ICT or the use of Frog VLE does help in increasing the level of students' achievements.

Based on the challenges and barriers discussed above, it is uncertain whether teachers will continue to use Frog VLE in English Language teaching or will remain to the old 'Chalk and Talk' method. Without finding ways to overcome these challenges and barriers, it would be difficult to prolong government initiatives in using Frog VLE in schools. Therefore, to implement Frog VLE in teaching and learning, fast actions need to be taken in order for it to be successful and benefited to teachers and students.

\section{Conclusion}

Based on the review above, there are a number of challenges occur in implementing the use of Frog VLE. In order for the teachers to use the platform in teaching and learning, the administrator needs provide sufficient amount of facilities to cater the need especially the teachers as well as the students. Each school has to reach a certain percentage of the usage of the Frog VLE to cater the KPI of the Ministry of Education. There is no doubt that integrating technology together with the teaching does have its challenges. The crucial challenges faced by the teachers were mostly on the incompetency of using Frog VLE as well as having poor internet connectivity or no access at all. Therefore, there is a need to investigate teachers' perception of using Frog VLE in the classroom particularly in primary school. The necessity of conducting an interview to the teachers are also important as the researcher will know the reality that is happening in schools. It is hoped that more research on teachers' perception of this Frog VLE in the classroom teaching especially focusing on the teaching of ESL will be carried out.

\section{References}

Ball, S. J. (2003). The teacher's soul and the terrors of performativity. Journal of education policy, 18(2), 215-228.

Bolster, A. S. (1983). Toward a more effective model of research on teaching, HarvardEducational Review, 53(3), 294-308.

Cheok, M.L., Wong, S.L. Ayub, F.A. \& Mahmud, R. (2017). Teachers 'perceptions of e-learning in Malaysian Secondary Schools, Malaysian Online Journal of Educational Technology (MOJET) $5(2), 14$

Cheok M.L., dan Wong S.L. 2016. Frog virtual learning environment for Malaysian schools: Exploring teachersâ€ $€^{\mathrm{TM}}$ experience. 201-209 
Darus, S. (2010). The Current Situation and Issues of the Teaching of English in Malaysia. Ritsumeikan Studies in Language and Culture Journal. 22 (1). 19-27 Retrieved from

http://www.ritsumei.ac.jp/acd/re/k-rsc/lcs/kiyou/pdf_22-1/RitsIILCS_22.1pp19-27_DARUS.pdf

Frog Asia.(2016).frogasia.https://frogasia.com/en/frog-vle/[3 April 2018]

Jani J., Muszali R., Nathan S. and Abdullah M. S.(2018). Blended Learning Approach Using Frog VLE Platform Towards Students' Achievement in Teaching Games for Understanding, J. Fundam. Appl. Sci.,10(5S),1130-1141.

Kaur, T. \& Hussein, N. (2015). Teachers' Readiness to Utilize Frog VLE: A Case Studyof a Malaysian Secondary School, British Journal of Education, Society \& Behavioural Science 5(1), 20-29. http:/ /www.sciencedomain.org/abstract.php?iid=656\&id=21\&aid=6026.

Malaysia Education Blueprint. ( 2016). Blueprint 2013-2025.(2013). Ministry of Education,Malaysia

Rani, N.S.A, Suradi, Z. \& Yusoff, N.H. (2014). An Analysis of Technology Acceptance Model, Learning Management System Attributes, E-satisfaction, and E-Retention. International Review of Management and Business Research 3(4), 1984-1996. http://www.irmbrjournal.com/papers/1420777229.pdf [4 April 2018].

Nithia, K., Yusop, F.D., \& Razak, R.A. (2015). Mobile learning for teaching and learning Science, Technology, Engineering and Mathematics (STEM): A review of literature. Economics, Social Sciences and Information Management (November), 173-176. http://www.crcnetbase.com/doi/10.1201/b19921-29.

Razali, N.Z., Bahador, Z. \& Saidon, M.K. (2016). Faktor-Faktor Yang Mempengaruhi Penggunaan Vle Frog Dalam Kalangan Guru di Sekolah Menengah, Proceeding of ICECRS 1(October), 1-9. http://ojs.umsida.ac.id/index.php/icecrs.

Nambiar, R., Nor, N.M., Ismail, K. \& Adam, S. (2017). New Learning Spaces and Transformations in Teacher Pedagogy and Student Learning Behavior in the Language Learning Classroom, 3L: Language, Linguistics, Literature ${ }^{\circledR}$ 23(4) http://ejournals.ukm.my/31/article/view/21548/7184 [23 April 2018].

Kamalludeen, R., Hassan, A. \& Nasaruddin, N.S.A. (2016). Student Usage Patterns of Vle-Frog, Journal of Personalized Learning 2(21), 86-94.

Sharifian, F. (2018). Metacultural Competence in English Language Teaching (ELT). The TESOL Encyclopedia of English Language Teaching, 1-6.

Songkram, N., Khlaisang, J., Puthaseranee, B. \& Likhitdamrongkiat, M. (2015). ScienceDirect E-learning system to enhance cognitive skills for learners in higher education, Procedia - Social and Behavioral Sciences 174, 667-673, https://ac.els-cdn.com/S1877042815006503/1-s2.0-S1877042815006503main.pdf?_tid=53bce84f-d6ac-4808-bf73953cb5ccf8e2\&acdnat=1524483830_bfd174315b967fe9e42513a77a925867 [9 April 2018].

Sudhir, S. K. \& Sunil, K. S. (2015). Ict Application in Education: An Overview, International Journal of Multidisciplinary Approach and Studies 2(1), 25-32.

Tinio, V. L. (2003). Ict in Education, e-ASEAN Task Force.

Suo, Y.J. \& Suo, Y.M. (2018). Perceptions and Practices of Blended Learning in Foreign Language teaching at USIM, ISSNOnline) European Journal of Social Sciences Education and Research Jan. Apr 12(1), 2411-9563. http://journals.euser.org/files/articles/ejser_jan_apr_18_v12_i1/Suo.pdf [10 April 2018].

Ying, H. S., Abdullah, A. N., \& Tan, H. (2018). Teachers'perception On The Vitality Of The English Language Among Primary School Students. Language \& Communication, 5(1), 46-62. 